3-3 885b Mel Gray \& Penny Crofts

\title{
PARTNERSHIPS: MARRYING THE STRENGTHS AND RESOURCES OF DIVERSE INTEREST GROUPS
}

Mel Gray (PhD), Professor of Social Work and Head of the School of Social Sciences, The University of Newcastle, New South Wales, Australia and Penny Crofts, Lecturer in Social Work, School of Social Sciences, The University of Newcastle, New South Wales, Australia

\begin{abstract}
This paper explores the growing importance of partnership development within the social services sector in Australia. It proposes that the social, political and economic factors giving rise to shifting priorities in this newly named "third" sector are encapsulated in the notion of social entrepreneurship being given impetus by the Federal Government's policy of mutual obligation, the findings of the Welfare Reform Group and the consequent Australians Working Together programme. It argues that community development is the ideal strategy for partnership development that fits well with the strengths perspective, where the emphasis is on mutual engagement in an equal relationship such that the collective assets and resources of the collaborating partners can be harnessed for the good of the community. The parallels between partnerships and human relationships are outlined and the role of the key sectors of community, business, government and non-government in the provision of social services are discussed. The paper ends with a discussion of community-business partnership development. Partnerships are seen to offer social workers with opportunities and challenges in the development of creative and innovative programmes aimed at social improvement.
\end{abstract}

The concept of "partnership" is gaining increasing attention in social welfare policy and practice. The notion of partnership gives a sharper edge to the more traditional and accepted practices of inter-agency collaboration, networking and referral. While the concept of partnership within and between the government and non-government human services sector is not an alien idea, the broadening of the concept to include possibilities for partnership with the business and economic sector in a changing policy and ideological environment poses significant challenges to dominant accepted wisdom within the sector. The rapid growth of the social entrepreneurship movement in Australia has given rise to significant debate about the possibilities and limitations of marrying social and economic objectives through inter alia community-business partnership and social enterprise development (Botsman \& Latham, 2001; Crofts \& Gray, 2001; Fitzgerald, 2000; Gray, Healy \& Crofts, 2003; Healy 2001; Horin, 2001; Simons, 2001; Zappala, 2001).

This paper outlines a social work perspective on factors putting partnership development on the welfare agenda, among them changing definitions of approaches to welfare, changing definitions of social justice, the changing nature of work, new responses of voluntary organisations, and the rise of the new social economy. It proposes that social entrepreneurship and community development respectively provide the context and strategy for partnership development in Australia. It briefly outlines the relationship between social work and community development before exploring the nature of partnerships and key role-players within the social services sector involved in partnership development. It ends with a brief look at community-business partnership development. The discussion flows from several premises about partnership development in social work: 
1. There is nothing about building partnerships that social workers do not already know: Social workers have the skills necessary for partnership building and engaging and networking with people at all levels.

2. Partnership building is a strengths-based approach: It involves identifying, locating and building on the assets, strengths, capacities and skills already existing in a given situation.

3. The only thing that gets in the way is our values: Social workers are sceptical about building partnerships, especially with business. They are also sceptical about social entrepreneurship, or social enterprise, because they tend to see it as antithetical to social justice goals and as an abdication of government responsibility for social service provision. Those involved in social enterprise are, in turn, sceptical of welfare workers, including social workers. Hence there is a lack of understanding between social workers and social entrepreneurs and the only way to bridge this gap is through dialogue.

4. Social enterprise will not go away and social workers need to become involved: Social enterprise is not new to social work. Social workers have the skills for social enterprise development. They are the same skills they need for community development. In fact, social enterprise is a form of assets-based community development. It rests on the identification of skills and resources that are marshalled for individual and community capacity building and empowerment.

5. Social workers can learn from business: Real empowerment occurs when clients and communities can sustain themselves - this means when they are economically empowered and able to support themselves financially. Hence social entrepreneurs believe that they offer an alternative to welfare dependency.

\section{FACTORS PUTTING PARTNERSHIP DEVELOPMENT ONTO THE WELFARE AGENDA}

The New Democrats in the USA and New Labour in the UK spawned a "new progressivism" or "third way" in Western politics, the cornerstones of which are said to be "equal opportunity, personal responsibility and the mobilization of citizens and communities" (Giddens, 2000:2). Also called "structural pluralism", it represents a public policy shift from wealth distribution to wealth creation, from a highly statist brand of social democracy (the welfare state) and right-wing, free market philosophy (neoliberalism) to a new social democratic approach characterised by "empowering rather than heavy-handed government" (Giddens, 2000:5). "Third way" thinking influenced Clinton's policies aimed at fiscal discipline, health care reform, investment in education and training, welfare-to-work schemes, urban renewal programmes and taking a hard line on crime and punishment, and Blair's policies relating to family life, crime and the decline of community. In Australia it is reflected in the Federal government's policy of mutual obligation and in its welfare reform policies, Families First and Australians Working Together. It attempts to "combine social solidarity with a dynamic economy (which requires) ... less national government, less central government, but greater governance over local processes ... and a break away from the old forms of welfare and social protection" (Giddens, 2000:5). It has led to an emphasis on improving the efficiency of the public service through greater monitoring of government performance, hence to a changing role for government, which includes contracting out for services and facilitating partnerships with and between all social and economic sectors.

Increasingly the non-government community services sector is emerging as a major site of service delivery and is being constructed as a "highly desirable location for the production of community or social services" (McDonald, 2000:85). A crucial aspect of this trend is the question of 
distribution of resources and sources of finance. As government moves increasingly away from direct service delivery to a steering role (McDonald, 2000) and promotes the responsibility of business for social investment, questions arise regarding the capacity of welfare service arrangements to meet goals of social equity and equal access to resources and services.

\section{CHANGING DEFINITIONS OF AND APPROACHES TO WELFARE}

In keeping with the aforementioned policy trends, changing public policies in most Western countries have given rise to the shrinking or commercialisation of public services referred to as "the shrinking welfare state". Government is no longer regarded as the main provider of social services, but is seen as the facilitator of social policies and conditions for greater citizen involvement in social provision. The "citizens" are local communities, government and nongovernment organisations, and the business or corporate sector. This "third way" represents a change from welfare state and neoliberal thinking (Giddens, 2000). The former sought to raise standards of living through income transfers and service provision offering cradle-to-grave coverage, while the latter placed its faith in the trickle-down effect of the market. Neither approach has been effective in reducing poverty and its attendant social problems. Hence a new social democratic approach involving greater collaboration between local communities, government and non-government organisations, and the business or corporate sector, is being seen as a better way to respond to people's social and economic needs.

\section{CHANGING DEFINITIONS OF SOCIAL JUSTICE}

According to Giddens (2000), the traditional social democratic approach elevated rights above responsibilities and identified social justice with equality of outcome. It resulted in increasing levels of public spending and expanding social benefits regardless of outcome. The new social democratic approach attempts to marry rights with responsibilities and input with outcome and has resulted in notions of mutual obligation reflected in welfare to work schemes.

\section{CHANGING NATURE OF WORK}

With the rise of the Information Revolution has come a change in the way in which we think about work and evaluate productivity. The "know-how" of the "wired worker" is a very different commodity from the "product" of the manual or industrial labourer. The information technology sector is the fastest growing employment sector within which more and more people are choosing to work on a contract basis from home as employers create conditions for the movable office such that employees can work anywhere at any time. With computerisation has come increasing job destabilisation within the traditional 9-5 work sector and the growing casualisation of labour, with work eating more and more into people's leisure time. There is a recognition that the market will not provide sufficient jobs within the industrial manufacturing sector as employers increasingly focus on trimming costs, improving efficiency and increasing profits. At the same time, government is becoming increasingly managerial and business-minded and no longer sees itself as the main provider of jobs. For example, in Australia more jobs are being created in the nongovernment sector than in the government community services sector. To combat rising unemployment, people are being called upon to become more "entrepreneurial" and to find alternative ways for income generation. Thus social services are being called upon to use partnership development as a vehicle for creating sustainable, income-generating programmes in local communities. 


\section{NEW RESPONSES OF VOLUNTARY ORGANISATIONS}

The voluntary, non-government or social and community services sector is increasingly being referred to collectively as the "social enterprise" or "third sector", giving the impression that new forms of community organisation are emerging. What is in fact happening is a new way of thinking about the non-government sector and its relationship to other sectors. This thinking is calling on existing social service organisations to develop new responses to the social, political and economic context in which they operate, as outlined above.

\section{THE RISE OF THE NEW "SOCIAL ECONOMY"}

In its attempt to overcome the dominance of the market, characteristic of neoliberal politics, the new "social economy" seeks to align a strong, facilitative government with empowered communities and a supportive economic sector. Business social investment, social entrepreneurship and partnership development are major driving forces in the new "social economy" (Spear, Defourny, Favreau \& Laville, 2001). They are strategies through which to apply business acumen to community causes such that there is a real transfer of economic power to disadvantaged individuals, groups and communities (Crofts \& Gray, 2001).

\section{SOCIAL ENTREPRENEURSHIP AS THE CONTEXT FOR PARTNERSHIP DEVELOPMENT}

The concept of social entrepreneurship has emerged in the context of complex political, economic and social changes occurring at global, national and local levels, in particular, the shifts away from the social welfare state and neoliberal approaches. It follows recognition of the apparent failure of these approaches to redistribute resources and to prevent unprecedented wealth creation alongside a growing gap between rich and poor. The "third way", as it has been called (Giddens, 2000), involves a much closer working relationship between the public, private and non-profit or "third sector" (Healy, 2001). It is driving policy changes in most Western countries. Its influence was apparent in Australia in the final report of the Reference Group on Welfare Reform, which concluded that "the social support system will be stronger and more sustainable if governments, business, not-for-profit organisations and communities work together to maximise opportunities for economic and social participation by individuals" (Reference Group on Welfare Reform 2000: Part 2-5). The Report outlined a range of processes to enhance opportunities for social and economic participation, the ethos of which is captured in the notion of social entrepreneurship, which "refers to integrated approaches to achieving "social" goals based on partnerships between communities and the institutions of business, government and the Third Sector" (Healy, 2001:1). Social entrepreneurship is consistent with community development since it places emphasis on people, not structures; creative and innovative approaches which operate "outside the box"; the application of business acumen to social goals; accountability to constituencies served and for outcomes delivered; opportunities for combining for-profit and not-for-profit initiatives; improved economic prosperity for disadvantaged constituencies; individual capacities for problem solving; and responsibilities as well as rights as encompassed by the notion of mutual responsibility.

\section{COMMUNITY DEVELOPMENT}

Community development comes with a chequered history and a great deal of baggage. It has been much maligned because of the way in which governments in the past used it, especially those working within the colonialist paradigm, to subdue local people. They tended to overlook indigenous knowledge, stifle authentic community participation and use a technocratic approach to 
community development favouring top-down, non-empowering approaches which depoliticised human needs.

In social work community development is seen as a particular approach to community intervention which is democratic, participatory, people-centred, focuses on process, works from the bottom up, and is often referred to as grassroots development. Capacity building, empowerment, consciousness-raising and participation are key strategies. As such, community development is consistent with social work's ethical theory, which embodies a set of humanistic values and promotes an egalitarian ideal of social justice which, among other things, does the following:

1. Places the interests of people as paramount and acknowledges the right of people to participate in their own development through an agreed-upon process of social improvement;

2. Challenges power structures and policy makers within them to become more responsive to the needs of individuals, especially where their needs and interests are overlooked for the sake of broader political, economic or social goals;

3. Strives to eliminate discriminatory or selective practices, which focus on sectional needs and interests.

The early British literature on community development portrayed it as a paternalistic, enabling strategy in terms of which it was in the best interests of people to help them to help themselves. It emphasised rational problem solving within a consensus-orientated model and was seen as totally apolitical (Batten, 1965; Biddle \& Biddle, 1965). North American writers, such as Dunham (1970:140), defined community development as the "organised efforts of people to improve the conditions of community life and the capacity of the people for participation, self-direction, and integrated effort in community affairs". Similarly Ross (1958) referred to the community (social) worker's role as being to enable the whole community to become involved in the identification of its own problems and to mobilise itself to deal with them. Rothman (1979) saw community development as a specific model of, or approach to, community practice along with community organisation, social planning and social action. He referred to it as locality development, which he defined as "a process to create conditions of economic and social progress for the whole community with its active participation and the fullest possible reliance on the community's initiative" (1979:26). Warren (1983) emphasised the importance of purposive planned change at the community level. He used a rational model of community development describing it as a "process of helping community people to analyse their problems, to exercise as large a measure of autonomy as possible and feasible, and to promote a greater identification of the individual citizen and the individual organization with the community as a whole" (1983:35).

Radical social work theorists challenged this apolitical stance, drawing attention to poverty as a major form of social oppression which required structural change (Bailey \& Brake, 1975; Biklen, 1983; Corrigan \& Leonard, 1978; Daniel \& Wheeler, 1990; Friedman, 1992; Galper, 1980; Mullaly, 1993). They adopted a critical (variously referred to within social work as radical, structural and feminist) perspective which viewed social problems as the result of the failures of liberal capitalism in the belief that social work practice involved working with oppressed people, its ultimate goal being the transformation of society. Drawing on Marxist ideas, their empowerment strategies were aimed at:

1. Consciousness-raising: Making oppressed people aware of the extent to which their problems were caused, not by their own wrongdoing, but by the context in which they lived. In redefining social reality in this way they translated personal troubles into political concerns; 
2. Normalisation: Making oppressed people see that they were not to blame for their poverty to overcome "blaming-the-victim" approaches;

3. Collectivisation: Focusing on collective interests to overcome individualism.

Community theorists favoured this radical perspective as one that provided useful insights into the way in which injustice and oppression arose and was maintained in society (Clark \& Asquith, 1985). Community development was seen to provide the means for working towards the elimination, or at least the reduction, of injustice and oppression in society.

The model of community development we advocate provides a holistic, integrated approach that can be used to harmonise social and economic objectives for the wellbeing of all people, especially the disadvantaged (Gray, 1997). It involves a form of helping relationship that seeks to empower communities to play an active role in efforts to improve their wellbeing that requires practitioners, whether from government or non-government agencies, to facilitate the exchange of power between power holders and local communities. It requires professional leaders willing to search for proactive, innovative solutions rather than only remedial responses to the challenges facing local communities. A facilitative model of community development therefore has the following characteristics:

- It is first and foremost a process where the means are valued as much as the ends;

- It values the local holding that people know best what they need;

- Accountability is primarily to the community rather than the agency employing the community development practitioner;

- It cannot happen in a moral vacuum, hence local culture, beliefs, values and politics are pivotal;

- Questions of sustainability are a matter of value and of practicality;

- It requires a holistic understanding where all sectors - political, cultural, social, economic, personal and spiritual - are taken into account;

- Most important for community-business partnership development, it provides a vehicle to marry together social and economic goals;

- It employs an anti-colonialist stance, valuing the local while linking the local to the global.

What, then, is the relationship between social work and community development? Ife (2001) provides a model of community-based social work within which to situate partnership development (see Figure 1). Casework involving individual and group relationships is the main means for linking clients to services and for working with clients within the service system. Through community practice the client becomes the community and social workers work with clients collectively within communities. Through community organisation social workers work to make the service system responsive to local community needs. Dunham (1970) referred to community organisation as a process of adjusting needs and resources. The service system is the locus from which partnerships are developed. 
FIGURE 1: IFE'S TYPOLOGY (1997)

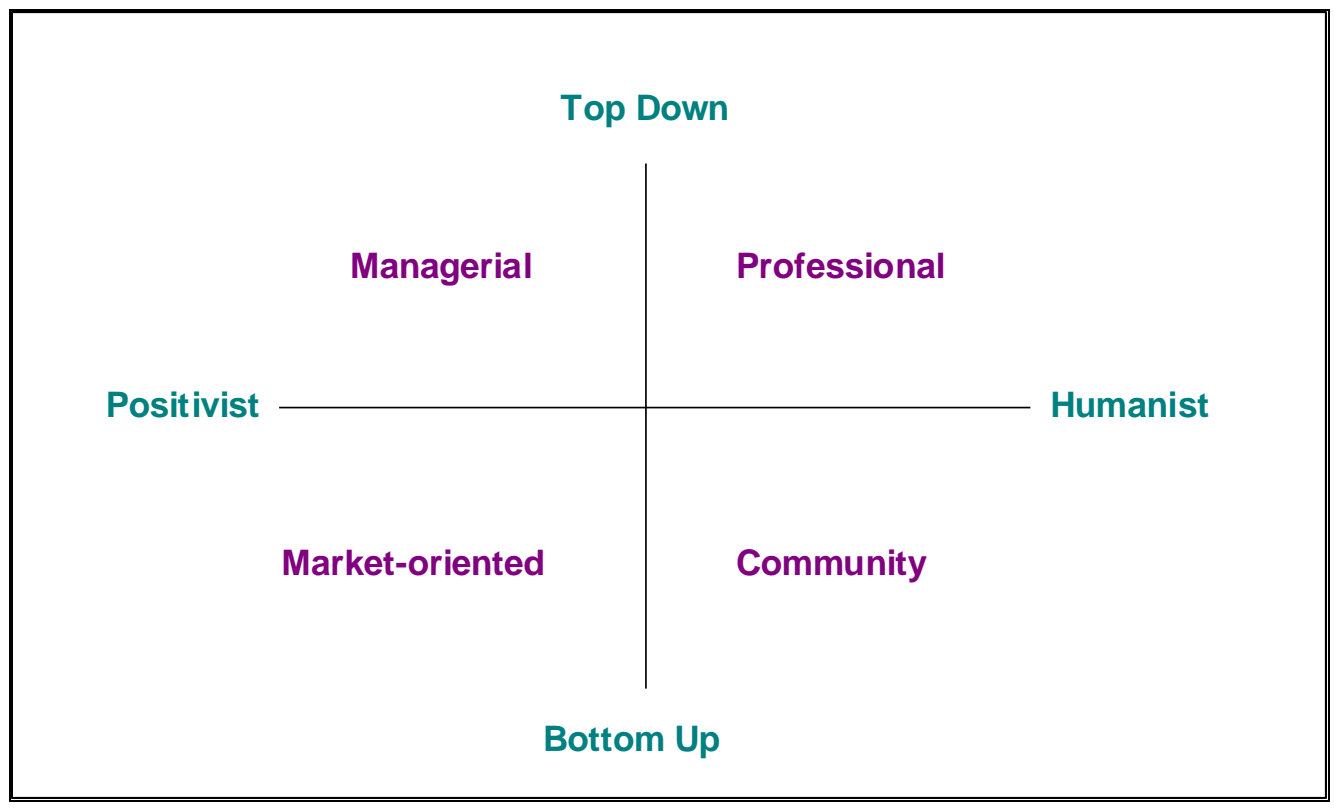

\section{PARTNERSHIP DEVELOPMENT}

The idea of cross-sectoral partnership development fits well with the strengths perspective where the emphasis is on mutual engagement in an equal relationship such that the collective assets and resources of the collaborating partners can be harnessed for the good of the community. Partnerships provide space for creative practice. They imply mutuality, exchange, sharing, and dialogue as the means of learning from one another how best to tackle local challenges. For some it is a difficult praxis for partnership usually involves long-term relationships. They go through the same stages and pitfalls as human relationships. They require adequate preparation and courtship, even if it is love at first sight. As with cross-cultural human relationships, cross-sectoral partnerships face the added challenge of predetermined assumptions, beliefs, values and prejudices, and include entrenched cynicism about motivations in the light of the policy and political context in which they are promoted. Due to their ideological perspectives and lack of practice in engagement with non-traditional partners, social workers have a long way to go in terms of developing acceptance of the notion of cross-cultural partnerships. They exhibit what might be called a Romeo and Juliet complex, that is, fear of the consequences of crossing entrenched boundary lines! There is an inherent tension between entertaining good possibilities and supporting conservative agendas (Crofts, 2002).

What precautions, then, might be put in place to provide protection against unsavoury partnerships? Using human relationships as a metaphor, Ife (2001) referred to preparation, engagement and marriage as follows:

Good preparation: We have to be clear about our intent and we have to ensure that there is equality in the relationship, that is, equal input. We need to be wary of seduction and manipulation and avoid being carried away by the first flush of excitement. What will it really be like to "get into bed" with this partner? What sort of family are you marrying into? Is the partner from a 
different culture, ethnic group or religion? What baggage does the partner bring? Will there be an ex hanging around who will get in the way? Does the partner have multiple relationships? Will there be conflicts of interest and conflicting obligations?

Engagement: After the preparation comes engagement. We need to be sure we will still like our new partner when we begin working closely with them.

Marriage: Next comes the marriage, the commitment to work together. It might well be stormy and conflict-ridden. It will be affected by our experiences in our past relationships. We might fear its permanence and the commitment we have made. Putting our passion into action can be difficult - performance anxiety, insufficient preparation and bad advice may all be present. And what happens when we hit turbulence? What do we do when we stumble upon our partner's indiscretions? What happens if the relationship does not work? The decision as to whether to stay and weather the storm or to leave and end the relationship is not an easy one. One in three marriages ends in divorce. How will you end it in such a way that you will still be talking to one another in the future?

Despite these pitfalls, with good preparation and clarity of goals and purpose, there is every likelihood that a successful partnership will develop and that it will carry through to a logical point of terminatison once the work is accomplished. Good preparation involves taking adequate precaution to ensure that your interests are served by the partnership, such as a binding legal agreement specifying the parameters of the partnership, accountability and the sharing of benefits and resources. A relationship of mutual trust is needed. There needs to be a public event to celebrate the partnership, a "marriage ceremony", and continuing celebrations and rituals for successes and anniversaries, ways to maintain the romance, publicly renew the commitment, and keep the excitement going. We need to understand power and its dynamics, the values we bring to the relationship and the context in which it takes place. Here Ife's (1997) typology of varying cultural perspectives is instructive (see Figure 2).

\section{FIGURE 2: IFE'S (2001) ${ }^{1}$ COMMUNITY-BASED SOCIAL WORK MODEL}

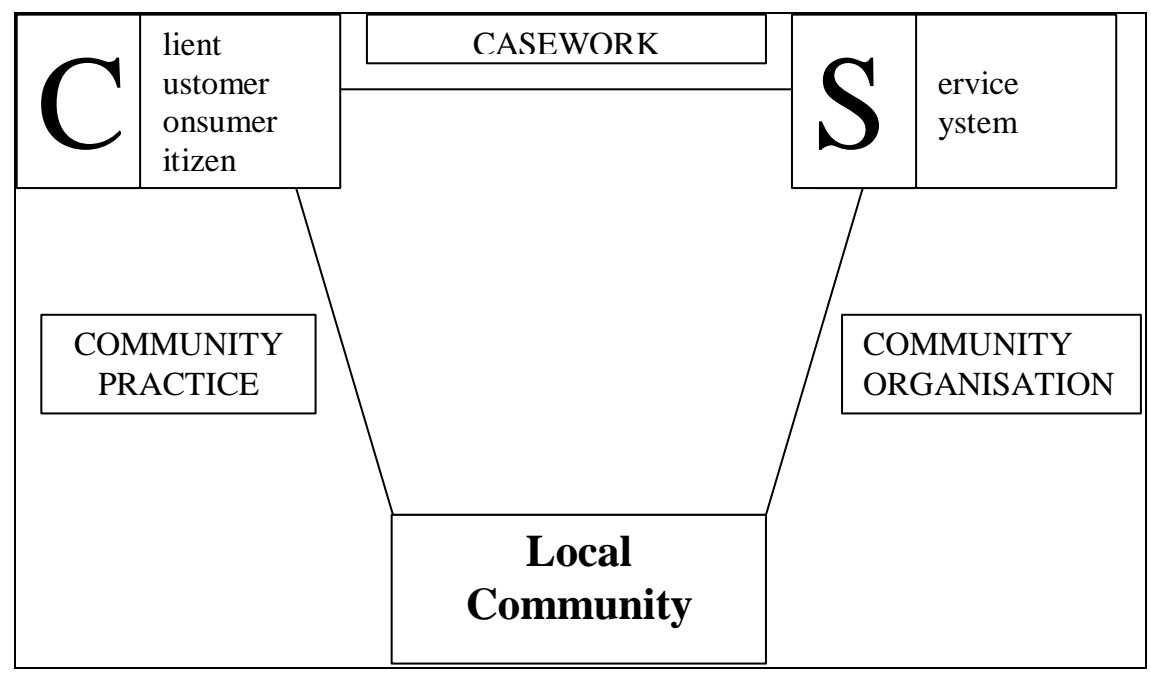

1 Presentation to Centrelink Workshop, Strategic Partnerships: Better Servicing Customers and Community Groups, December 2001. 
Managers who are market-oriented and professionals who are community focused would tend to want to use bottom-up processes laying emphasis on the importance of consumer or client participation and input. They would show preference for a community development approach (Ife, 1996). Managers and professionals who are more accustomed to working in a top-down mode would tend to be more focused on expert input, talking mainly to those who are deemed to know best. They would prefer a social planning approach. In the business world managers are more accustomed to basing action strategies on sound quantitative research. For them, numbers and profits are priorities and they would tend to use a positivist approach. Professionals and communities more interested in the people involved and in the consequences of decisions on participants would tend to value more qualitative, humanistic approaches. Increasingly professionals, including social workers, some of whom are also managers, are being called upon to show results, to prove the cost effectiveness of their programmes, and to demonstrate tangible outcomes. This creates tensions for those concerned with social justice outcomes and community development. Yet both "cultures" are needed. The tangible and intangible are equally important. Thus bringing together these cultures through partnerships has enormous potential to marry the strengths and resources of diverse interest groups to achieve balanced outcomes. Managers who only pursue business interests and who ignore social goals are as dangerous as communities that pursue only their own political interests at the expense of other parties affected by their actions. Likewise, social workers who pursue their own professional interests at the expense of client interests are as narrow as those who believe in the capacity of the market to provide. Thus the balance of worldviews, cultures, perspectives and paradigms creates the synergy needed for creative solutions and innovative programmes.

\section{THE ROLE OF KEY SECTORS IN PARTNERSHIP DEVELOPMENT}

The partnerships that we are speaking about involve bringing together four key sectors, namely, the community, business or the economic sector, government and the non-government services sector (see Figure 3). Each sector is seen as having a pivotal role to play in social service provision and community development.

\section{FIGURE 3: ROLE-PLAYERS IN PARTNERSHIP DEVELOPMENT}

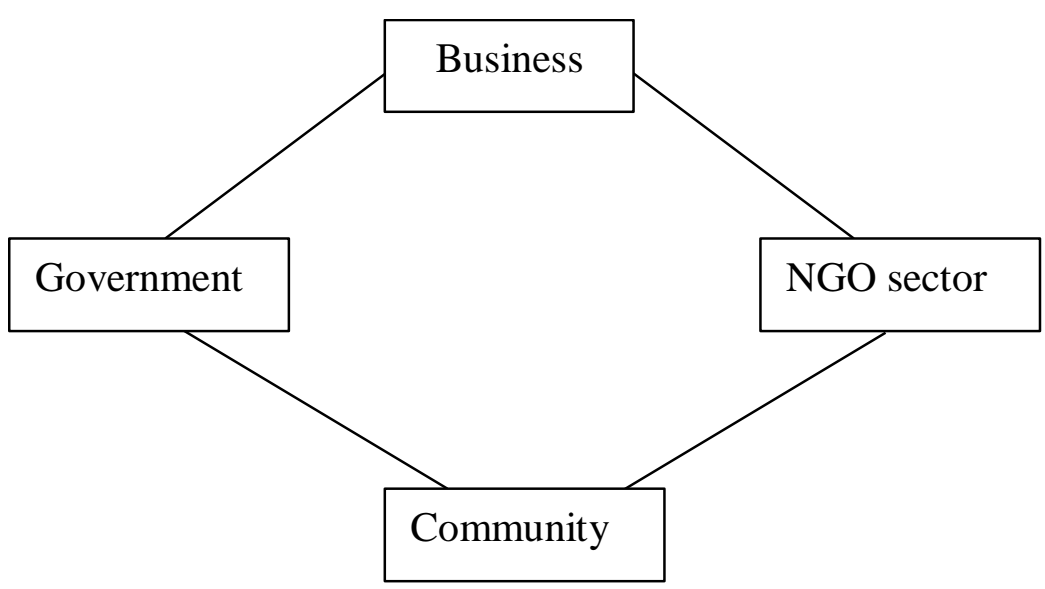




\section{THE ROLE OF GOVERNMENT}

Strong rather than big government plays an important role in creating the policy and context for flexible, creative and innovative solutions to social problems and issues; in ensuring that there is adequate social infrastructure at the local and regional levels to ensure active engagement of local communities in regional development; for ensuring that there are strategically placed resources in the most needy communities; and in needs assessment and resource allocation. Government needs to take a flexible approach to allow for diversity rather than pursue "one size fits all" policies and projects.

\section{THE ROLE OF THE COMMUNITY}

The community is seen as both a resource and a site of intervention and as having the social and economic capacity to direct its own destiny through active community involvement in the provision of care, community building and economic development activities rather than leaving these key roles to experts, professionals and paid carers (Gray et al., 2003). Assets-based community development focuses on resources rather than needs, viewing the community's collective assets, including its own knowledge about potential solutions, as pivotal to community development (Kretzmann, 2001).

\section{THE ROLE OF THE NON-GOVERNMENT SERVICES SECTOR}

The non-government sector is a major player in the provision of social services with a wealth of knowledge about the capacity of, and challenges facing, local communities. Community members already play a major role in service provision as volunteers. However, partnership development requires a different view of clients as partners and participants rather than only as recipients or consumers of social services. This represents a major change of paradigm, for with the rights of service users to services comes their responsibility to participate in their own social and economic development.

\section{THE ROLE OF BUSINESS}

The Federal Government's Summit on Regional Issues held in 1999 identified the need for business to invest in capacity building in regional and local communities as a key priority (Department of Transport \& Regional Services, 2000). It set the scene for research into the current activities and potential interest, demands, constraints and capacities of the business community for business social investment (Crofts \& Gray, 2001). Its articulation into a policy of mutual obligation produced the notion of community-business partnership development. Business social investment, or corporate citizenship, is a term used to describe a range of social support strategies undertaken by business in association with social and community service organisations. The concept reflects a move in philanthropy away from a tradition of patronage and gratitude towards the notion of social investment to build social capital (Timmons, 1999). Social investment by business is thought to be one means by which the social capital of a region may be enhanced through the development of ties and networks across economic and social systems. Since Robert Putnam (cited in Gittell \& Vidal 1998) identified the role of social capital in regional governance and economic development in Italy, there has been a growing interest in defining and measuring social capital (Cox, 1998; Gittell \& Vidal, 1998). The main elements of social capital for Putnam were trust and co-operation developed through networks and norms that fostered collaborative effort to achieve shared objectives. Putnam concluded that regional differences in economic and social wellbeing could, in part, be attributed to the presence or absence of social capital. 


\section{COMMUNITY-BUSINESS PARTNERSHIP DEVELOPMENT}

The social services sector is being increasingly called upon to work with business rather than against it. By the same token, through the Australian Federal Government's Business and Community Partnerships Program, business is being encouraged to consider a more strategic approach to charitable giving (Burke, 1996). There is pressure on business to become more responsive to its local environment, to pay attention to social factors that damage economic infrastructure and performance, and to develop partnerships to address the causes and consequences of social problems, such as poverty and violent crime (Vidaver-Cohen, 1998). There is thus a growing interest in the capacity for business social investment to deliver immediate benefits for business both to enhance profitability and performance and to improve the social environment. Recognition of the social role of business acknowledges inter alia that

- Business is a stakeholder in the community and, like other stakeholders, needs to be understood and taken into account in terms of its experience and interests. To ignore a business perspective in community development initiatives, and hence to deny the effective participation of business as a stakeholder, is to jeopardise project outcomes and the achievement of social goals;

- Business engagement with social issues reflects its active role in social matters because of its direct experience of the impact of social problems. Business ideas on possible solutions may differ significantly from a social work approach, but insofar as business suffers financial loss and personal pain through impacts such as crime, anti-social behaviour, homelessness, family breakdown and substance abuse, it will demand that its interests and rights be acknowledged. It is therefore very important to engage with business in an effort to influence its understanding of social problems and to encourage a social justice and human rights perspective characteristic of the social work approach;

- There are inextricable links between the economic and social health of localities. It is therefore important for social and community workers to have some understanding not only of macroeconomics and the impacts of policy at this level, but also of the functioning of the local economy in terms of its structure, organisation and future development. Related to this is the need for an understanding of the significant economic as well as social contribution of the "third" sector as an economic force in a local economy;

- Stereotypes of a business perspective, like stereotypes of a social perspective, can reflect certain realities, but can also limit possibilities for co-operative action;

- Business organisations can contribute valuable resources, such as expertise, financial support and, more importantly, support and promotion for particular initiatives in which they have a stake;

- The knowledge and skill inherent in community development practice can be effectively applied to working with business as a key stakeholder for positive outcomes.

\section{CONCLUSION}

This paper explored the growing importance of partnership development within the social services sector and proposed that the factors giving rise to it in Australia were encapsulated in the notion of social entrepreneurship which was being given impetus by the Federal Government's policy of mutual obligation, the findings of the Welfare Reform Group and the consequent Families First and Australians Working Together programmes. It presented community development as the ideal 
strategy for partnership development within a strengths perspective with its emphasis on mutual engagement in an equal relationship such that the collective assets and resources of the collaborating partners could be harnessed for the good of the community. The parallels between partnerships and human relationships were outlined and the role of the key sectors of community, business, government and non-government in social service provision was discussed. It ended with a discussion of community-business partnership development. Partnerships are seen to offer social workers challenges and possibilities for the development of creative and innovative programmes aimed at social improvement.

\section{REFERENCES}

BAILEY, R. \& BRAKE, M. (eds) 1975. Radical social work. London: Edward Arnold.

BATTEN, T.R. 1965. The human factor in community work. London: Oxford University Press. BIDDLE, W.W. \& BIDDLE, L.J. 1965. The community development process. New York: Holt, Rinehart and Winston.

BIKLEN, D.P. 1983. Community organising: Theory and practice. Englewood Cliffs, NJ: Prentice-Hall.

BOTSMAN, P. \& LATHAM, M. (eds) 2001. The Enabling State. Annandale: Pluto Press

BURKE, L. 1996. How corporate social responsibility pays off: Strategic benefits for firms. Long Range Planning, (29):495-502.

CLARK, C.L. \& ASQUITH, S. 1985. Social work and social philosophy: A guide to practice. London: Routledge \& Kegan Paul.

CORRIGAN, P. \& LEONARD, P. 1978. Social work practice under capitalism: A Marxist approach. London: MacMillan.

COX, E. 1998. Measuring social capital as part of progress and well-being. In: ECKERSLEY, R. (ed) Measuring progress: Is life getting better? Collingwood: CSIRO Publishing.

CROFTS, P. 2002. Crossing the great divide: Connecting the economic and social sectors at the regional level. Paper presented at the Western Australian South West Area Consultative Committee National Conference Inspiring Regional Australia, Bunbury, October 16-18.

CROFTS, P. \& GRAY, M. 2001. Social entrepreneurship: Is it the business of social work? Paper presented at the $16^{\text {th }}$ Asia and Pacific Social Work Conference, Singapore, 31 July -3 August 2001.

DANIEL, P. \& WHEELER, J. 1990. Social work and local politics. London: MacMillan Education Ltd.

Department of Transport \& Regional Services 2000. Regional Australia Summit: Working Group, Theme 11, Final Report.

[http://www.dotrs.gov.au/regional/summit/outcomes/reports/theme11]

DUNHAM, A. 1970. The new community organisation. New York: Thomas Crowell \& Sons.

FITZGERALD, R. (Internet 2000) Social obligation. Paper presented at the National Volunteering Conference Volunteering: Beyond 2000. [http://www.csc.nsw.gov.au]

FRIEDMAN, J. 1992. Empowerment as the politics of alternative development. Cambridge, MA.: Blackwell. 
GALPER, J. 1980. Social work practice: A radical approach. Englewood Cliffs, New Jersey: Prentice-Hall.

GIDDENS, A. 2000. The third way and its critics. Cambridge: Polity Press.

GITTELL, R. \& VIDAL, A. 1998. Community organising: Building social capital as a development strategy. London: Sage.

GRAY, M. 1997. The contribution of community social work to social development. Journal of Applied Social Sciences, 21(1):45-51.

GRAY, M.; HEALY, K. \& CROFTS, P. 2003. Social enterprise: Is it the business of social work? Australian Social Work, 56(2):149-162.

HEALY, K. 2001. Social enterprise: A strategy or paradigm for the sector. Impact, Bulletin of The Australian Council of Social Services, August, $1 \& 16$.

HOOPER, A. 2001. In the eye of the storm: Community development responses to enterprise culture. Critical Social Work, 2(1). [http://www.criticalsocialwork.com]

HORIN, A. 2001. End of Charity. Sydney Morning Herald, $11^{\text {th }}$ August 2001

IFE, J. 2001. Community partnerships: Theory and practice. Workshop presentation Centrelink's Strategic Partnerships: Better Servicing Customers and Community Groups. Parramatta, Sydney, 12 December 2001.

IFE, J. 1997. Rethinking social work: Towards critical practice. South Melbourne, Australia: Longman.

IFE, J. 1996. Community development. South Melbourne, Australia: Longman.

KENNY, S. 1999. Developing communities for the future: Community development in Australia. ( $2^{\text {nd }}$ ed) Melbourne: Nelson ITP.

KRETZMANN, J. 2001. Keynote address at the Second Australian Family Strengths Conference, University of Newcastle, 2-5 December 2001.

LEITMANN, S. \& CRAWFORD, F. 2001. Connecting, blending and joining community participation with entrepreneurial thinking: A way forward? Paper presented at the $\mathbf{1 6}^{\text {th }}$ Asia and Pacific Social Work Conference, Singapore, 31 July - 3 August, 2001.

McDONALD, C. (2000) The third sector in the human services: Rethinking its role. In: O'CONNOR, I.; SMYTH, P. \& WARBURTON, J. Contemporary perspectives on social work and the human services. Australia: Pearson Education.

MULLALY, R.P. 1993. Structural social work: Ideology, theory and practice. Toronto: McClelland \& Stewart Inc.

PUTNAM, R. 1993. Making democracy work. New Jersey: Princeton University Press.

Reference Group on Welfare Reform 2000. Participation support for a more equitable society. Final report of the Reference Group on Welfare Reform, August 2000.

[http://www.facs.gov.au/internet/facsinternet.nsf/aboutfacs/respubs/nav.htm\#Welfare]

ROSS, M.G. 1958. Case histories in community organisation. New York: Harper \& Row. 
ROTHMAN, J. 1979. Three models of community organization practice, their mixing and phasing. In: COX, F.M.; ERLICH, J.L.; ROTHMAN, J. \& TROPMAN, J.E. (eds) Strategies of community organization. (3rd ed) Itasca, Illinois: F.E. Peacock Publishers.

SIMONS, R. (Internet 2001) Social enterprise: Partnerships for sustainable change. Paper presented at the National Social Policy Conference Competing visions. Social Policy Research Centre University of New South Wales.

[http://www.sprc.unsw.edu.au/nspc2001/papers/Paper 6 1.pdf]

SPEAR, R.; DEFOURNY, J.; FAVREAU, L. \& LAVILLE, J.-L. 2001. Tackling social exclusion in Europe: The contribution of the social economy. Aldershot: Ashgate.

TIMMONS, G. 1999. Communities leading change. Regional Australia Summit.

VIDAVER-COHEN, D. 1998. Public-private partnership as a strategy for crime control: corporate citizenship makes a difference. Business and Society Review, 100-101, 21-31.

WARREN, R. 1983. A community model. In: KRAMER, R.M. \& SPECHT, H. (eds) Readings in community organization practice. (3rd ed) Englewoods Cliffs, New Jersey: Prentice-Hall, Inc.

ZAPPALA, G. 2001. From 'charity' to 'social enterprise': Managing volunteers in public serving non-profits. Australian Journal of Volunteering, 6(1):41-48. 